\title{
Using Multidisciplinary Design Principles to Improve the Website Design Process
}

\author{
Sangeeta Karmokar \\ Faculty of Creative Technologies \\ Auckland University of Technology \\ New Zealand \\ sangeeta.karmokar@aut.ac.nz \\ Harminder Singh \\ Faculty of Business, Economics \& Law \\ Auckland University of Technology \\ New Zealand \\ harminder.singh@aut.ac.nz \\ Felix B Tan \\ School of Business \\ Excelsia College \\ Australia \\ Felix.Tan@excelsia.edu.au
}

\begin{abstract}
An organization's success in e-business is significantly affected by the quality of its website. However, many websites are unable to retain the attention of their customers, arguably because they only cater to some of the needs of their customers. This study adopts a design science approach to develop a new methodology for designing websites that addresses the psychological, sociological, and cognitive needs of individual users. The methodology is based on multidisciplinary principles drawn from the field of design, as they provide a framework for structuring the various concerns of users. This study contributes by developing a website design methodology anchored in users' needs, so that the websites it produces are successful in achieving their goals.
\end{abstract}

Keywords: website, design science, multidisciplinary, users 


\section{Introduction}

A key component of an e-business strategy is a high-quality website (Lee \& Kozar, 2006; Levy \& Powell, 2005). Despite the importance of a high-quality website for online business, many websites are poorlydesigned and difficult to use (Albers \& Still, 2011; Fisher, Craig \& Bentley, 2002; Johnson \& Henderson, 2012; Schubert \& Dettling, 2001). In addition, badly-designed websites can also have a negative impact on a firm's image (Tomayess \& Pedro, 2014; Qutaishat, 2013).

Focusing on various aspects of a website, such as the quality of visual communication (Bostock \& Heer, 2009), the efficiency of task completion (Kules \& Shneiderman, 2007), the level of emotional usability and its overall value to users (Boztepe, 2007), can help firms improve the satisfaction of their customers with their websites. The challenge with such an approach is that website designers are provided with a laundry list of features which are "good to have", and they may find it difficult to discern which are more relevant for each particular project.

The premise of this study is that, in the light of this situation, focusing on the process by which a website is designed may provide a more valuable contribution, than examining the attributes of the final "product" (the website) (Fig. 1). This argument is built on the principle that a good design process will lead to a good product (Pries-Heje, Baskerville, \& Venable, 2008). Since a website's features are incorporated during the design process, improving the design process may lead to a website containing the features that are appropriate for and relevant to its users.

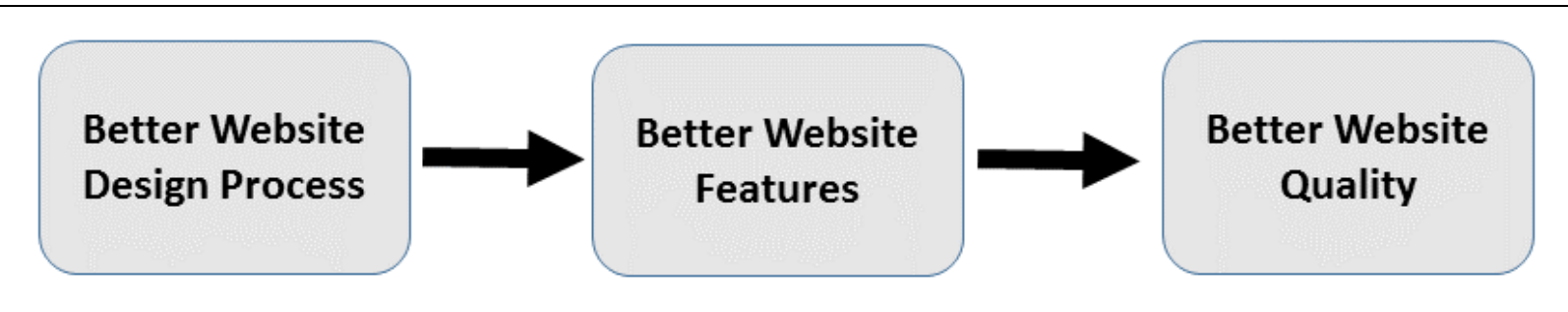

Figure 1 - Impact of Website Design Process

This study begins by evaluating current website design processes in terms of their focus on improving user satisfaction, a key aspect of a high-quality website. While few studies have examined how website development work is actually carried out, it is widely recognized that the website design industry does not have a standard process for designing websites, and website development relies heavily on the knowledge and experience of individuals or teams of developers and their practices (AlQirim, 2004). The design methodologies used in the industry (Abels, White, \& Hahn, 1998; Garrett, 2002; Kvan, 2000; Nielsen, 1993; Spinuzzi, 2005) incorporate users in two ways: i) for surfacing their goals at the initial requirements gathering stage of the design process, and ii) for obtaining their feedback during the usability tests near the end of the design process. The broader notion of user value is largely unexplored and much emphasis is instead placed on usability (Acharya, Kagan, Lingam, \& Gray, 2008; Green \& Pearson, 2011; Nielsen, 1993; Norman, 2002).

More recently, standard themes and templates have been provided by vendors, such as WordPress, Joomla and Drupal, for website designers. While these predesigned templates have made the design process easier for developing generic websites, their level of customisation varies, and in some cases, provides little scope for 
integrating the wider needs of users. Another issue that, unlike a website developed using the methodology in this paper, there is little guidance on how well these templates are able to meet the various needs of users.

Usability may be an important goal for websites, but is inadequate by itself as an attribute of a high-quality website. Other factors, such as the psychological and social needs of users, should also be incorporated by website designers because they help build trust and customer loyalty (Krieger, 2008). This difference in priorities occurs because, instead of users, designers focus on the technology and key participants in the social context surrounding their project, such as those who have requested the information being presented or whom they are trying to persuade with the information gathered and packaged (Lamb \& Kling, 2003).

The lack of a clearly-defined methodology and a narrow focus on usability mean that many websites are poorly-designed and thus ineffective (Jiang, Chan, Tan, \& Chua, 2010). Organisations will thus benefit from the creation of a well-structured design process that obtains the input of users at multiple stages, and incorporates a broader understanding of user value (beyond usability). The study aims to answer the question: How can a website design process better incorporate the needs of users?

The next section reviews current website design practices and highlights their limitations. Next, design processes that incorporate users are examined to identify the multidisciplinary principles that guide them. Following a short introduction to design science, the methodology that will be used in this study, the new website design process is described, along with an account of a case study where the new process was used. The results of an evaluation exercise, where three groups of individuals assessed different aspects of the process, are presented in the next section. The paper concludes with a discussion of the practical and theoretical implications of this study, and its limitations.

\section{Literature Review}

This study's aim is to use multidisciplinary design principles to improve the website design process so that the websites that are produced by this process will be a better fit for the needs of their users. Before doing so, we need to clarify the role that users play in the design of IT artefacts and their needs. This section will review the literature in a few related areas: human-computer interaction $(\mathrm{HCl})$, website design methodologies, usability, and multidisciplinary design.

\section{Human-computer Interaction}

Human-computer interaction $(\mathrm{HCl})$ is the study of the issues that arise when people encounter computer-based technology, and how understanding these can help improve the design of technology (Hooper \& Dix, 2012). $\mathrm{HCl}$ uses principles from various domains such as anthropology, communication studies, social psychology, ergonomics, sociology and computer science (Brown, 1999; Carroll, 2003; Shneiderman, 1998). The more technical camps of $\mathrm{HCl}$ are dominated by the ethos of engineering and its emphasis on by applied research; thus, research here focuses on knowing what systems to build and what problems to solve (Kjeldskov \& Paay, 2012).

Traditional $\mathrm{HCl}$ research focuses on efficiency, effectiveness, satisfaction and product usability, and understanding human emotions and needs when using computers is still quite a neglected issue in $\mathrm{HCl}$ design (Dybala, Ptaszynski, Rzepka, \& Araki, 2010; Issa \& Turk, 2012). Some progress has been made in developing "affective systems" that are capable of recognizing and appropriately responding to human emotions and behaviours but these have not been adopted by mainstream designers (Lopatovska \& Arapakis, 2010). 
Methodologically, there is a lack of studies in exploring rich real-world use cases, contexts and user needs to gain a deeper understanding of users (Kjeldskov \& Paay, 2012). In the next section, we examine the application of $\mathrm{HCl}$ practices in the specific context of website design.

\section{Website Design Methodologies}

There are many areas of overlap between $\mathrm{HCl}$ and website design, particularly when it comes to usability, cultural awareness, the evaluation of web-based systems, interfaces for web/mobile/ubiquitous computing, aesthetics, motivation, social participation, trust, empathy, responsibility, and privacy (Shneiderman, 2007). There is no one particular design process that web designers use, and various processes have been developed in recent years such as the iterative design model (Lowe \& Eklund, 2002), the user-based design process (Abels, White, \& Hahn, 1998) and participatory design (Spinuzzi, 2005). Besides these, some researchers have focused specifically on the usability of websites, an important aspect of website success (Kim, Young, \& Neimeyer, 2008; Tan, Tung \& Xu, 2009; Tung, Xu \& Tan, 2009). Usability is defined as the ease of use and acceptability of a system (Nielsen, 1993). These studies examine how the usability needs of users can be integrated into the design process through methods such as the early involvement of users, assessments of their usability requirements, and the use of usability tasks to evaluate the design.

Current website design methodologies focus on: a) clarifying the functional requirements of users and, b) the usability of websites, in terms of their overall appearance, navigation, functionality and interaction (Table 1).

\begin{tabular}{|c|c|c|}
\hline METHOD/REFERENCE & FOCUS OF DESIGN PROCESS & LIMITATIONS \\
\hline $\begin{array}{l}\text { Usability Approach (Nielsen, } \\
\text { 1993) }\end{array}$ & $\begin{array}{l}\text { - Users' usability needs } \\
\text { - } \quad \text { Mental models of task completion } \\
\text { - Repeated usability evaluation }\end{array}$ & \multirow{5}{*}{$\begin{array}{l}\text { Other needs of users, } \\
\text { such as their } \\
\text { psychological, } \\
\text { emotional and cognitive } \\
\text { needs, are no } \\
\text { considered. }\end{array}$} \\
\hline 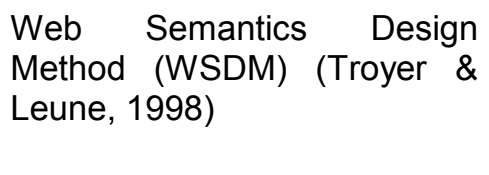 & $\begin{array}{l}\text { - Identification of website audience } \\
\text { - Identification of users requirements, } \\
\text { focus and motivation } \\
\text { - Efficient look and feel for the users }\end{array}$ & \\
\hline $\begin{array}{l}\text { User-based Design Process } \\
\text { (Abels et al., 1998) }\end{array}$ & - Initial requirements of users & \\
\hline $\begin{array}{l}\text { Participatory Design } \\
\text { Methodology (Garrett, 2002) }\end{array}$ & $\begin{array}{l}\text { - Understanding users' expectations and } \\
\text { use of the website } \\
\text { - Emphasis on functional, interaction and } \\
\text { visual design }\end{array}$ & \\
\hline $\begin{array}{l}\text { Participatory Design Process } \\
\text { (Spinuzzi, 2005) }\end{array}$ & - Users' usability needs & \\
\hline $\begin{array}{l}\text { Iterative Design Model (Lowe } \\
\text { \& Eklund, 2002) }\end{array}$ & - Focus on clients' needs & $\begin{array}{l}\text { Users' requirements, } \\
\text { and their psychological, } \\
\text { emotional and cognitive } \\
\text { needs are not } \\
\text { considered. }\end{array}$ \\
\hline
\end{tabular}


The challenge with this emphasis on system features is that, in the real world, the individuals who ordered the artefact to be built (the "clients") are sometimes not the same people who will use it (the "users"), and those who compile the requirements are not the ones who will design the system (Holzinger, 2005; Lamb \& Kling, 2003). One remedy for this is to involve users at the initial stages of the design process. When users are involved in the design process, they can design the outcome they desire, helping to increase its acceptance. Embedding users in the design process encourages other users to provide input and adopt the end-product (Humphreys, Leung, \& Weakley, 2008).

While there are other methods for testing usability, such as action analysis and indirect methods, few designers are aware of these alternative methods, and most are unable to quickly determine which method is best suited for a particular design situation (Holzinger, 2005). Moreover, such methods are time-consuming and require a high level of expertise on the designer's part (Holzinger, 2005). Users do not necessarily evaluate the complete design, since there is no mechanism to ensure that the entire design is explored, leading to evaluators sometimes focusing too heavily on only one section (Holzinger, 2005).

Software development methodologies, such as the agile and waterfall methods, are used for designing software. The basic concept behind them is that there is a well-defined process by which an application is conceived, developed and implemented. Their use for website development is complicated by a few issues. First, time schedules for website development are relatively short, often being less than one or two months, compared to most other types of software applications that have longer time schedules. Second, graphics, videos, sound and other types of media are often core components of a website, unlike many other commercial software.
Thus, developing websites is a highly complex problem consisting of many dimensions from various disciplines that must be addressed for web development to be successful. Agile methods have evolved to address some of the limitations of planned and structure-driven approaches. While they are iterative in nature, none of the existing agile processes explicitly include principles and practices for understanding and verifying usability and user experience requirements. The methodologies discussed above are used in the website design industry but most of these are based on generic principles of design, usability, business goals, ornamental features and technological capabilities. All of these aspects are important for a good website but omit an important part of the process - end-users and their needs. The new design process discussed in this paper is a process based on the perspective of end users, how it will be understood by them, how their latent needs will be integrated in the interface and the process of embedding the user experience. It is worth noting that this approach may not be suitable for all website design projects, as some website owners may prefer a generic template from a vendor such as WordPress, Drupal or Joomla because their goal is to complete the website as fast as possible. The design process presented in this paper will be suitable for those designers who want to create a user experience that can accommodate and support the behaviors, emotional needs and social values of users, in a way that users will perceive as being natural and satisfying.

This call to understand users in their natural states has been paralleled by the rise in the prominence of user-centered design more broadly (Boztepe, 2007). The challenge is thus to develop a website design process that adequately captures the multiple aspects of users' needs, going beyond usability and functional requirements. The next section examines different ways of involving users in design processes. 


\section{Methods of User Participation}

The success of an e-business interface depends on user participation (Black, 2007; Lille, Stappers, \& Lugt, 2009; Terry \& Standing, 2004). A successful e-business interface needs to be designed around the needs and wants of users so that they engage with the site and use it well. There is a growing recognition that providing superior value for users is instrumental for business success (Cagan \& Vogel, 2002; Kim \& Mauborgne, 2005; Vandermerwe, 2000). In current information systems research, however, the notion of user value remains largely unexplored (Lamb \& Kling, 2003). Moreover, within the complex social settings that commonly constitute organizations, individuals do not always have the opportunity to choose the systems they would prefer to use.

While user participation has been covered extensively in the systems development literature (McLeod, MacDonell, \& Doolin, 2007), only a few studies have discussed it in the context of website design. This section reviews four approaches for encouraging user participation in a design process: participatory design (Mclntyre-Mills, 2009; Spinuzzi, 2005), collaborative design (Krieger, 2008), user-centered design (Brown, 2009; Bullinger, Bauer, Wenzel, \& Blach, 2010; Garrett, 2002; Norman, 2002) and user innovation (Hippel, 1986).

\section{Participatory Design}

Participatory design is characterized by user involvement (Spinuzzi, 2005). It uses various methods, such as ethnographic observations, interviews, artefact analysis and protocol analysis, to study the tacit knowledge developed and used by those who work with a particular technology. Participatory design tends to focus narrowly on the artefact, rather than the overall workflow (Spinuzzi, 2005).

\section{Collaborative Design}

Collaborative design is the process of designing in a team that includes designers as well as members of other professions (Kvan, 2000). Collaborative design can be thought of as joint problem-solving. It means working with others on shared goals in which the team attempts to find solutions that satisfy all concerned (Kvan, 2000). However, collaborative design can suffer if there are too many participants or too few to make an effective decision. Similarly, if there is a lack of understanding and trust in the team, then the project duration increases.

\section{User Innovation}

The core concept of user innovation is that users are the first to identify the problem and develop a prototype of what later becomes a commercial product or process or service (Morrison, Roberts, \& Hippel, 2000). However, the user innovation method is limited to the experiences of a lead user and not the target market as a whole. The challenge is that lead users may not be well-positioned to identify and evaluate the novel attributes of familiar products that lie outside real-life experience (Hippel, 1986).

\section{User-Centered Design (UCD)}

User-centered design (UCD) is the process of designing a tool, such as a user interface, from the perspective of how it will be understood and used by a user (Garrett, 2002; Norman, 1982). UCD approaches the task of problem-solving by seeking to understand end-users' needs, aspirations, and goals, and the environmental conditions and constraints in which they live (Bhan, 2012). The basic idea behind UCD is that the needs of users shall dominate the interface design (Norman, 1982), although other aspects of the information system, such as functionality and behavior, also matter. The growing popularity of ecommerce has greatly bolstered the appeal of usability and UCD, as users can take their business elsewhere with just one mouse click. Poorly-constructed sites can cause half of a website's visitors to shift to another website (Mao, Vredenburg, Smith, 
\& Carey, 2005). To prevent this, UCD is frequently prescribed.

\section{Multidisciplinary Interface Design}

To design a human or user-centered interface, designers need to understand humans and the mechanisms by which they process data. We all think and process data differently, and the data processed by human minds are affected by known and hidden factors (Saariluoma, Parkkola, Honkatanta, Leppanen, \& Lamminen, 2009). There is thus a need to draw on different disciplines to develop designs that address these various aspects of our understanding. Zhang and Von Dran's (2000) study has classified some of these features into hygiene and motivators model also. Hygiene factors are those whose presence makes website functional and serviceable such as usability, motivators factors, on other hand are those that add value to the website and contributes to the user satisfaction such as social needs and aesthetics of the interface. Taking a broader approach, multidisciplinary design covers both hygiene and motivational factors in its design process (Zhang \& Von Dran, 2000).

One way of incorporating different disciplines into design is through the uses and gratification theory (Blumler \& Katz, 1974). This theory argues that individuals take an active part in the communication process and because they are goal-oriented in their media use, they actively choose media products based on their needs. This theory was developed in the context of traditional media, such as TV, magazines, or radio (McGuire, 1974), but has been extended to the online environment (Luo, 2002). These studies of users' attitudes, social behavior, usability aspects, customer satisfaction and cognitive requirements are valuable for designers when they design websites because they provide insight into how online users become customers, especially loyal customers (Cho \& $\mathrm{Ha}$, 2011).
Another way of engaging with the multidisciplinary aspects of design is by using the human-centered design principles of Brown (1999) and Shneiderman (1998). According to them, interface design is a multi-disciplinary study because various disciplines contribute to the human decision-making process (Figure 2). Thus, understanding a user's processing model provides a framework for appreciating how systems are used (Brown, 1999). If designers have a good understanding of the disciplines underlying the processing model, they will be able to design interfaces that will be well-utilized. For example, visual graphics can provide users with not just the information that they seek, but also a pleasant experience (Shedroff, 1999). Designs that build trust are necessary for electronic interactions so that individuals and businesses feel safe and do not feel they will be taken advantage of (Roy, Dewit, \& Aubert, 2001; Wang, 2005; Cyr, 2008) Good designs should pay attention to the cognitive needs of their users, so that they can find the information they need and process it effectively (Spivey, 2007). With the rapid increase in online shopping, navigation, and visual and information design not only increase user satisfaction but also help build trust and loyalty among diverse customers (Cyr, 2008).

The different domains in Figure 2 play a vital role in the interface design process, but little attempt has been made to integrate them in design (Shneiderman, 2007). The multidisciplinary frameworks of Brown (1999) and Shneiderman (1998) are broader than the uses and gratifications theory, in that they cover more attributes and needs of users. In addition, they have been used for designing interactive displays in various contexts (e.g. Stasko, Görg, \& Liu, 2008; Fei, Lin, \& Chen, 2007; Zhao et al., 2008). The uses and gratifications theory, in contrast, is more useful in contexts where the aim is to compare different websites or to track user reactions over time. Integrating user participation and multidisciplinary principles in the design process increases 
the quality of the outcome, user satisfaction, and reduces the risk of failure. Given these factors, we decided to use Brown's (1999) and Shneiderman's (1998) multidisciplinary design principles to design a new website design process.

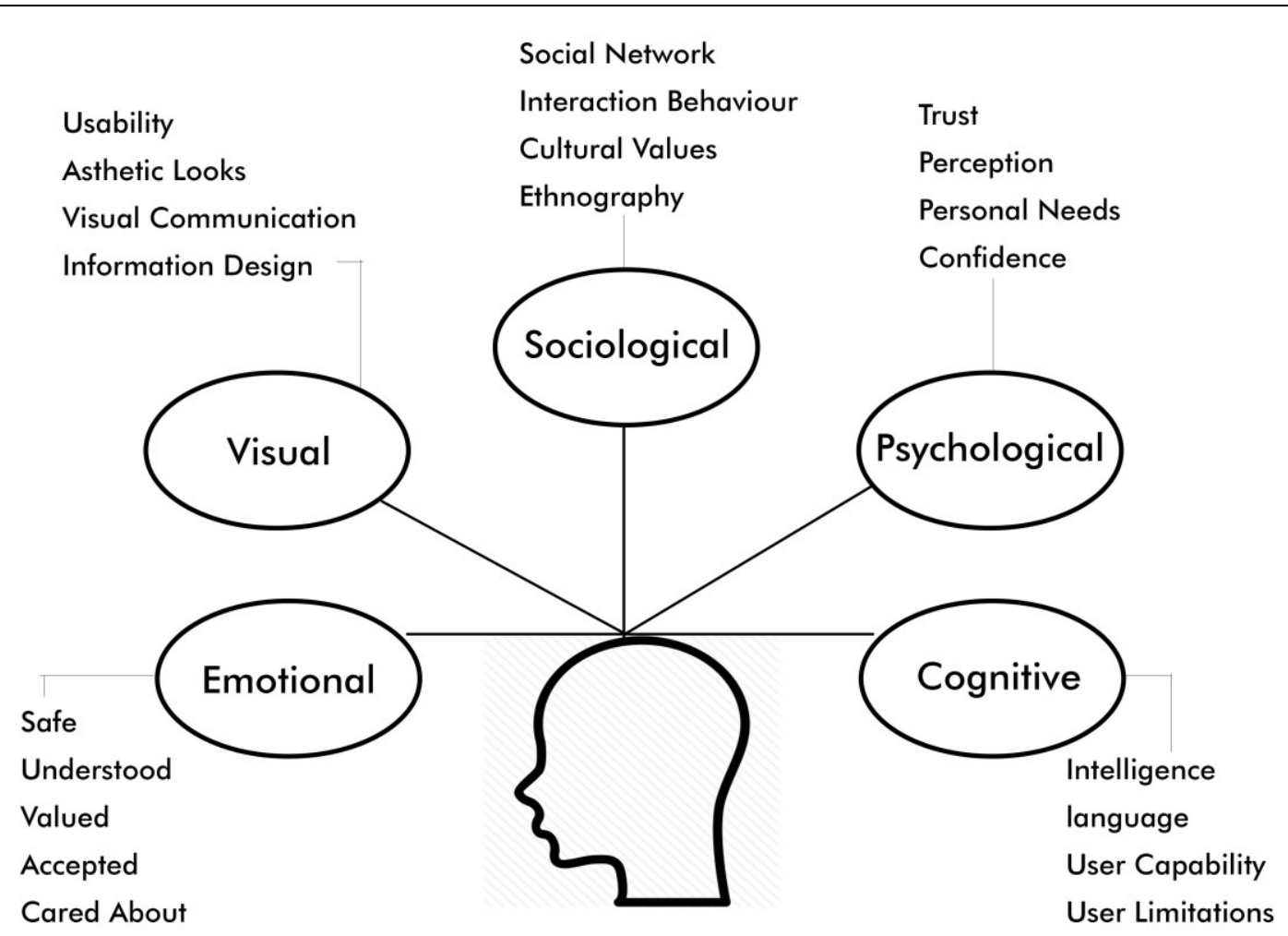

Figure 2 - Disciplines involved in User Centered Design (Brown, 1999; Shneiderman, 1998)

\section{Multidisciplinary Website Design Process}

This section details how the artefact, the "Multidisciplinary Design Process", was designed and instantiated in a case study. The preceding sections have shown that users play a limited role in current website design processes. Even in the domain in which they are most heavily engaged (usability evaluation), the structure of the process may not lead to useful, reliable or accurate results. This situation reflects Lamb and Kling's (2003) argument that the user concept is too narrowly defined in the research and practice of IS design, development, and evaluation. Despite the popularity of the user experience, understanding user satisfaction and preferences remains a challenge. The methods and models that assist in comprehending the dynamic changes of users' needs tend to ignore the importance of users' holistic experiences in relation to usability and $\mathrm{HCl}$. By relying on individualistic models that emphasize task models, ergonomic factors, and cognitive psychodynamics, research in this domain has adopted a limited view of users.

To achieve the goal of broadening the role of users in the website design process, the study used a design science approach. Design science is a suitable approach for this study because it provides a rigorous process for designing and evaluating artefacts that solve observed problems, and 
for communicating the results to various audiences, as well as contributing to research (Hevner et al., 2004). While routine design is the application of existing knowledge to organizational problems, design science involves finding new solutions to previously unsolved problems or better and more efficient solutions to previously solved problems (March \& Smith, 1995).

According to Hevner et al. (2004), effective design research must provide clear contributions in the areas of design artefacts, design construction knowledge and/or design evaluation methodologies. Researchers, reviewers and editors must use their creative skills and judgement to determine when, where and how to apply each of these guidelines. The focus is not on evaluating the outputs of the design process but on the methods and the frameworks used to integrate users' needs in the website design process.

A key aspect of design science is that designing the artefact requires researchers to identify theories that enable users of the artefact to reach their desired ends using the means available to them while satisfying laws in the problem environment (Hevner et al., 2004). In the information systems (IS) field, the literature around design theories is scattered and appears under different labels, such as the constructive approach (livari, Hirschheim, \& Klein, 1998), the system development approach (Gregor \& Jones, 2007; Nunamaker, Chen, \& Purdin, 1991) and the design science approach (Hevner, March, Park, \& Ram, 2004; March \& Smith, 1995). The common focus of these design theories is how an artefact can be built (development process knowledge) and what the artefact should look like when it is built (design principles). Thus, these design theories prescribe how a design process can be carried out effectively and feasibly
(Walls, Widmeyer, \& El-Sawy, 1992), so as to improve the effectiveness and utility of IT artefacts to solve real-world business problems (Hevner \& Chatterjee, 2010).

This approach contrasts with the view of design theories in the broader field of design (Table 2). A search of the literature revealed that no design science researchers have used any of the design theories in the table. This may be because these theories are different from what is commonly understood to be a "design theory" in IS design science. While IS design science theories describe the procedure for developing new artefacts, traditional design theories provide guidelines for designers so that the designs they produce are aesthetically pleasing, perform their task effectively, and fit well into their overall context. IS design science theories (methodologies) can be used to develop a new website design process (the goal of this study), but they do not explain how or why the new process will be effective. In this sense, traditional design theories are similar to kernel theories (Venable, 2006) - utility theories that make an assertion that a particular type or class of technology is useful in solving or improving a problematic situation. We draw on the evolution in $\mathrm{HCl}$ research to guide our search: as it has shifted its focus from a narrow view on usability - increasing the efficiency and effectiveness of task completion - to more broadly considering the human experience (Zimmerman \& Forlizzi, 2008), it has expanded the type of theories it relies upon. In the same way, we seek to find the most appropriate framework for incorporating users into the design of their computing experience. In this study, the utility theories that are used for solving the problem are Brown (1999) and Shneiderman's (1998) multidisciplinary design principles. 


\begin{tabular}{|l|l|}
\hline \multicolumn{2}{|l|}{ Table 2 - Design Theories } \\
\hline DESIGN THEORIES & DESCRIPTION \\
\hline Classic Design Theory & $\begin{array}{l}\text { A classic design is one that has stood the test of time. Most classic designs } \\
\text { are effortless and straightforward. The theory gives brief descriptions of the } \\
\text { elements of design, such as line, shape, space, texture, value and colour } \\
\text { (Lauer \& Pentak, 1985). }\end{array}$ \\
\hline Gestalt Theory of Design & $\begin{array}{l}\text { Gestalt theories of visual perception were developed by German } \\
\text { psychologists in the 1920s. These theories attempt to describe how people } \\
\text { tend to organize visual elements into groups or unified wholes when certain } \\
\text { principles are applied (Moore \& Fitz, 1993). }\end{array}$ \\
\hline Cognitive Load Theory & $\begin{array}{l}\text { Cognitive load theory (CLT) originated in the 1980s and underwent } \\
\text { substantial development and expansion in the 1990s (Paas, Renkl, \& } \\
\text { Sweller, 2003). Cognitive load theory is a learning theory of psychology } \\
\text { that attempts to explain human behaviour by understanding our thought } \\
\text { processes. }\end{array}$ \\
\hline Pattern Theory & $\begin{array}{l}\text { Grenander introduced the term 'pattern theory' in the 1970. The software } \\
\text { community embraced the pattern vision for its relevance to problems that } \\
\text { had long plagued software design in general and object-oriented design in } \\
\text { particular. }\end{array}$ \\
\hline Semiotics Theory & $\begin{array}{l}\text { Semiotics, also called semiotic studies or semiology, is the study of signs } \\
\text { and their related processes (Eco, 1979). Semiotics is important for } \\
\text { designers as it allows us to understand the relationships between signs, } \\
\text { what they stand for, and the people who must interpret them. }\end{array}$ \\
\hline
\end{tabular}

\section{Design of the New Process}

The new design process (Figure 3) consisted of two rounds of user interaction. In the first round, we use interviews to integrate usability principles (Garrett, 2002; Nielsen, 1993; Norman, 2002) and the client's (management's) needs. After the wireframes (webpage schematics or blueprints) were developed, the users were again interviewed to see if the wireframes met their multidisciplinary needs. In this way, the new artefact (the design process) integrates business objectives and the broader needs of users. 


\section{Round One of Design Phase}

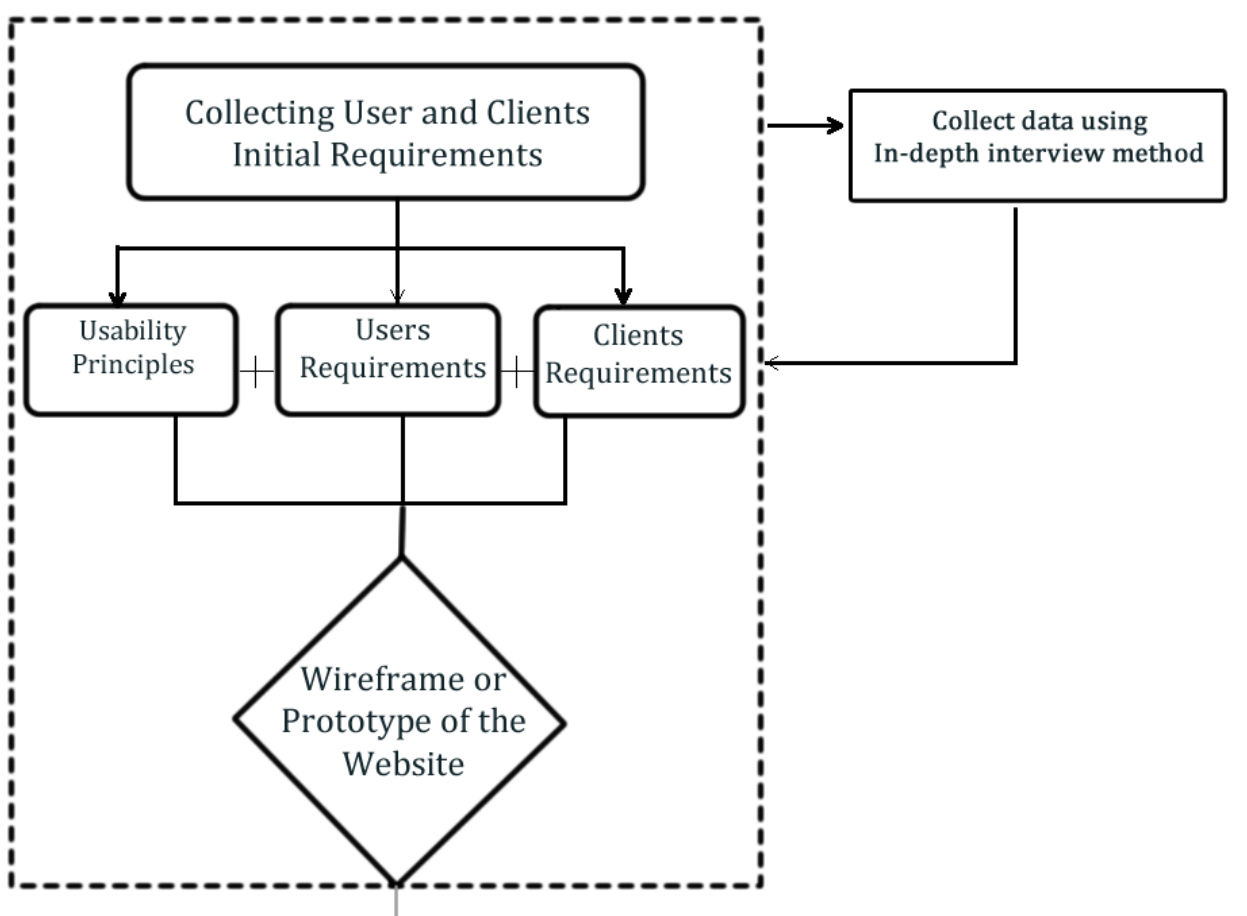

\section{Round Two of Design Phase}

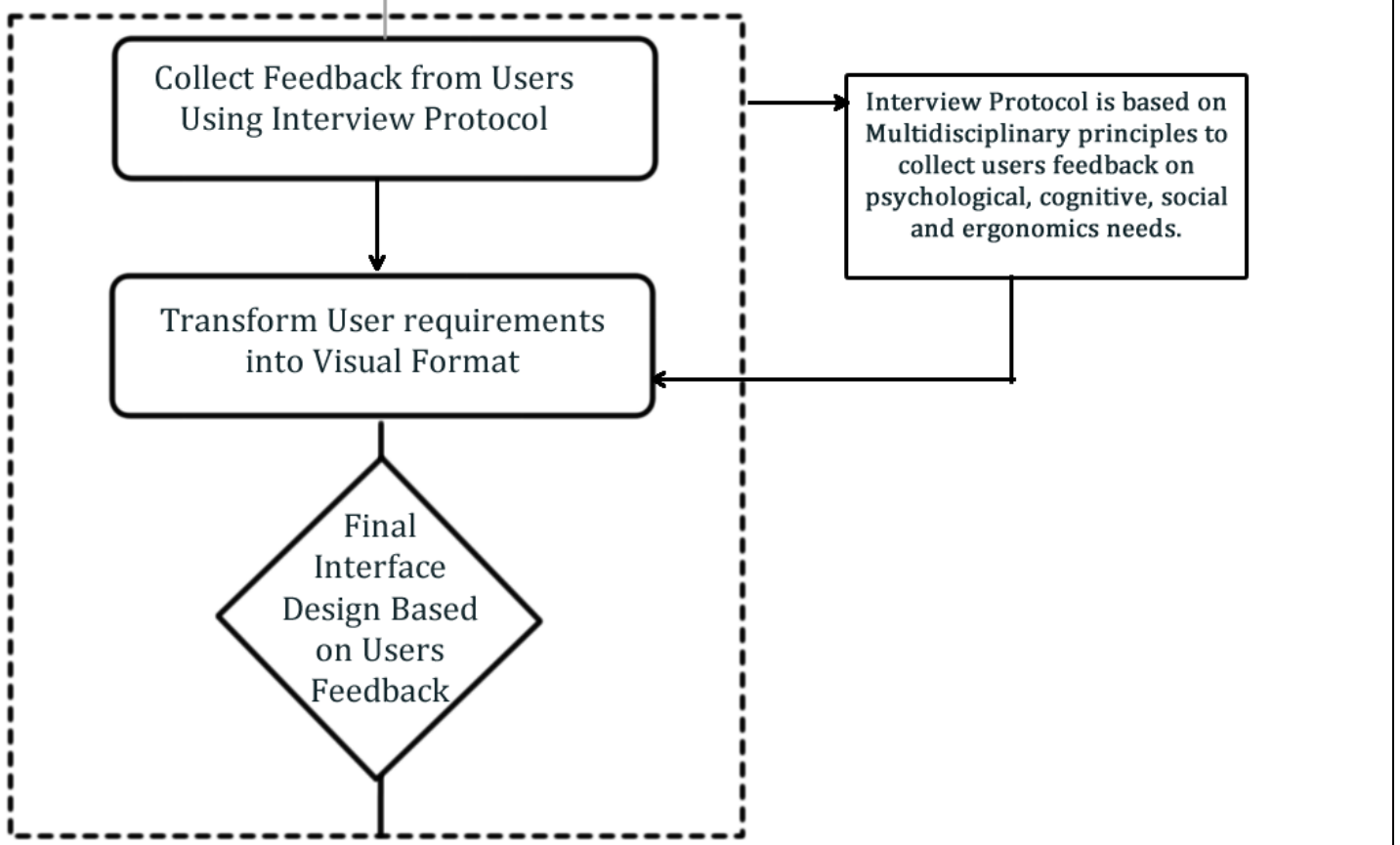

\section{Figure 3 - Flow of the new Multidisciplinary Design Process}




\section{Instantiation of the Multidisciplinary Design Process}

Hevner et al. (2004) list five different methods for evaluating an artefact created through design science: observational, analytical, experimental, testing, and descriptive. In this study, observational, analytical and testing methods were used. After the new process was designed, its utility was assessed by using it to develop a website for a particular SME. This section relates how this occurred in the form of a case study, and comprises the observational evaluation of the artefact. Following this, the new artefact's utility was also evaluated by asking individuals to complete certain tasks on the new website, and by asking expert designers for their professional opinions. These two steps were the testing and analytical assessments of the artefact. They will be described in the section after this.

\section{Design Process: Round One}

A web designer who was willing to participate was contacted, and one of his SME clients agreed to take part in the study. The client is a recruitment agency for students keen on careers in sports and sports coaching. Students who are recruited are offered scholarships with US universities and professional coaching services. The firm was a suitable choice for this study because it was a small organization that wanted to redesign its website. Its existing website was not appealing to their target market, and its management wanted to refresh it by integrating the requirements of its users: students, coaches and parents.

Data Collection: The requirements of the client and targeted users were collected through interviews and provided to the designer. The interview questions were about the users' and client's expectations of the website, and were based on usability principles and user requirements (Axelsson,
Melin, \& Lindgren, 2010; Nielsen, 1993; Norman, 2002; Troyer \& Leune, 1998; Virzi, 1996). The management of the firm provided information about the objective, purpose, target audience and content requirement of the website to the researcher and designer. Three target markets for the website were identified: tertiary student athletes between the ages of 17 and 20, professional sports coaches and parents. After the target market was identified by the client, the researcher selected five users who were willing to participate in the study. The users were selected because they were familiar with the Internet and had an interest in sports.

Design Phase: The designer was provided with feedback from the interviews, as well as information on usability design principles (Nielsen, 1993; Norman, 2002). The results indicated that trust was the main issue for users across all three groups when using the website, instead of usability issues, such as navigation, look and feel, download time and simplicity. This indicated that the website needed to establish connectivity and build trust with users to build their confidence. Based on the feedback provided by the researcher, the designer designed wireframes and provided them to the client for feedback. Figure 4 is an example of the wireframes provided. After receiving approval from the client (SME's management) for the initial wireframes, the designer integrated the design, color and look and feel into the wireframes.

\section{Design Process: Round Two}

User feedback: Users were interviewed for their feedback on the "filled-up" wire frames (Figure 5). The aim in this round was to find out how well the website met their psychological, emotional, sociological and cognitive needs. The users commented in their feedback that Figure 5 had a wellconstructed layout with appealing images, an effective color scheme and a good balance of text and images. All the elements that connected with the users' needs were integrated in the layout. 


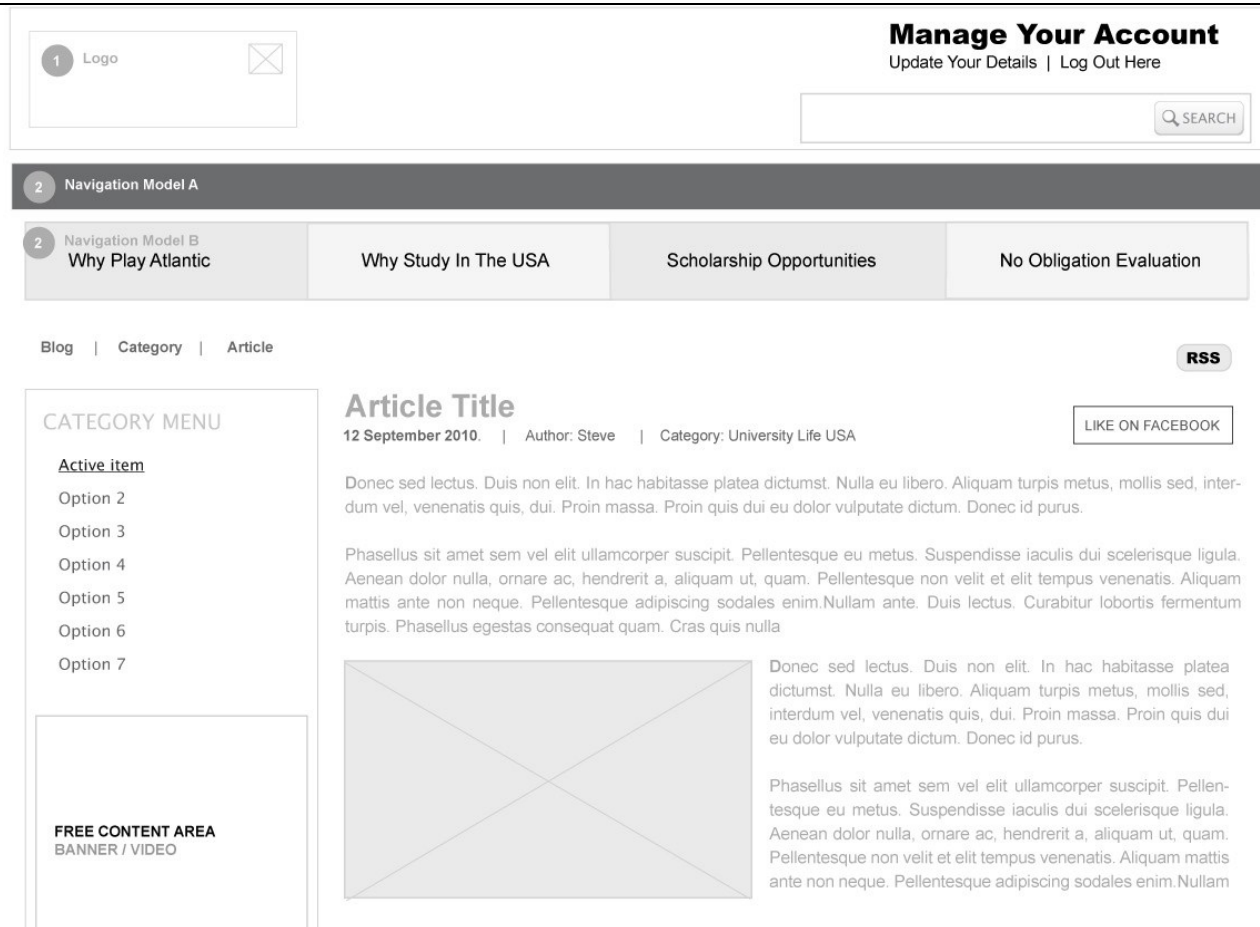

Submit A Comment

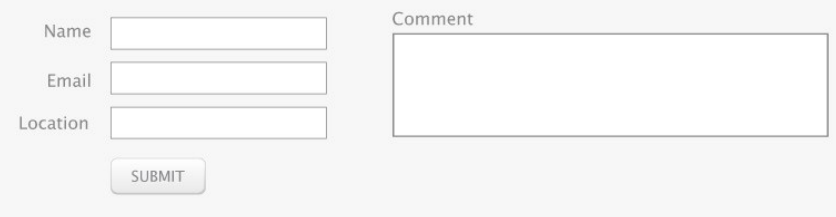

Comments

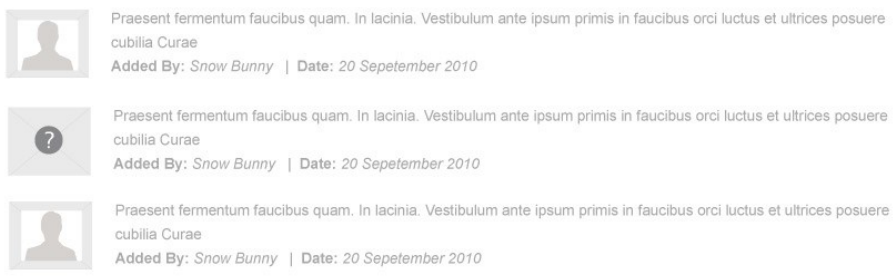

\begin{tabular}{|c|c|c|c|c|}
\hline \multicolumn{2}{|c|}{$\begin{array}{l}\text { Sign up for exclusive updates } \\
\text { and receive the latest placment news, events details }\end{array}$} & First Name & \multicolumn{2}{|c|}{ Email Address } \\
\hline \multicolumn{5}{|c|}{ Aenean dolor nulla, ornare ac, hendrerit a, aliquam (5) Supporting Links } \\
\hline - Donec sed lectus. & - Donec sed lectus. & - Donec sed lectus. & \multirow{2}{*}{ FACEBOOK } & \multirow{2}{*}{$\begin{array}{l}\text { Play Atlantic Agent Login } \\
\text { Aenean dolor nulla. }\end{array}$} \\
\hline - Duis non elit. In hac & - Duis non elit. In hac & - Duis non elit. In hac & & \\
\hline - habitasse platea dictumst. & - habitasse platea dictumst. & - habitasse platea dictumst & & \multirow{4}{*}{$\begin{array}{l}\text { Play Atlantic Coach Login } \\
\text { Aenean dolor nulla. }\end{array}$} \\
\hline - Nulla eu libero. Aliquam & - Nulla eu libero. Aliquam & - Nulla eu libero. Aliquam & TWITTER & \\
\hline - urpis metus, mollis sed, & - urpis metus, mollis sed, & - urpis metus, mollis sed. & & \\
\hline - nterdum vel, venenatis & - nterdum vel, venenatis & - nterdum vel, venenatis & YOUTUBE & \\
\hline
\end{tabular}

\section{Figure 4 - Wireframe Example}




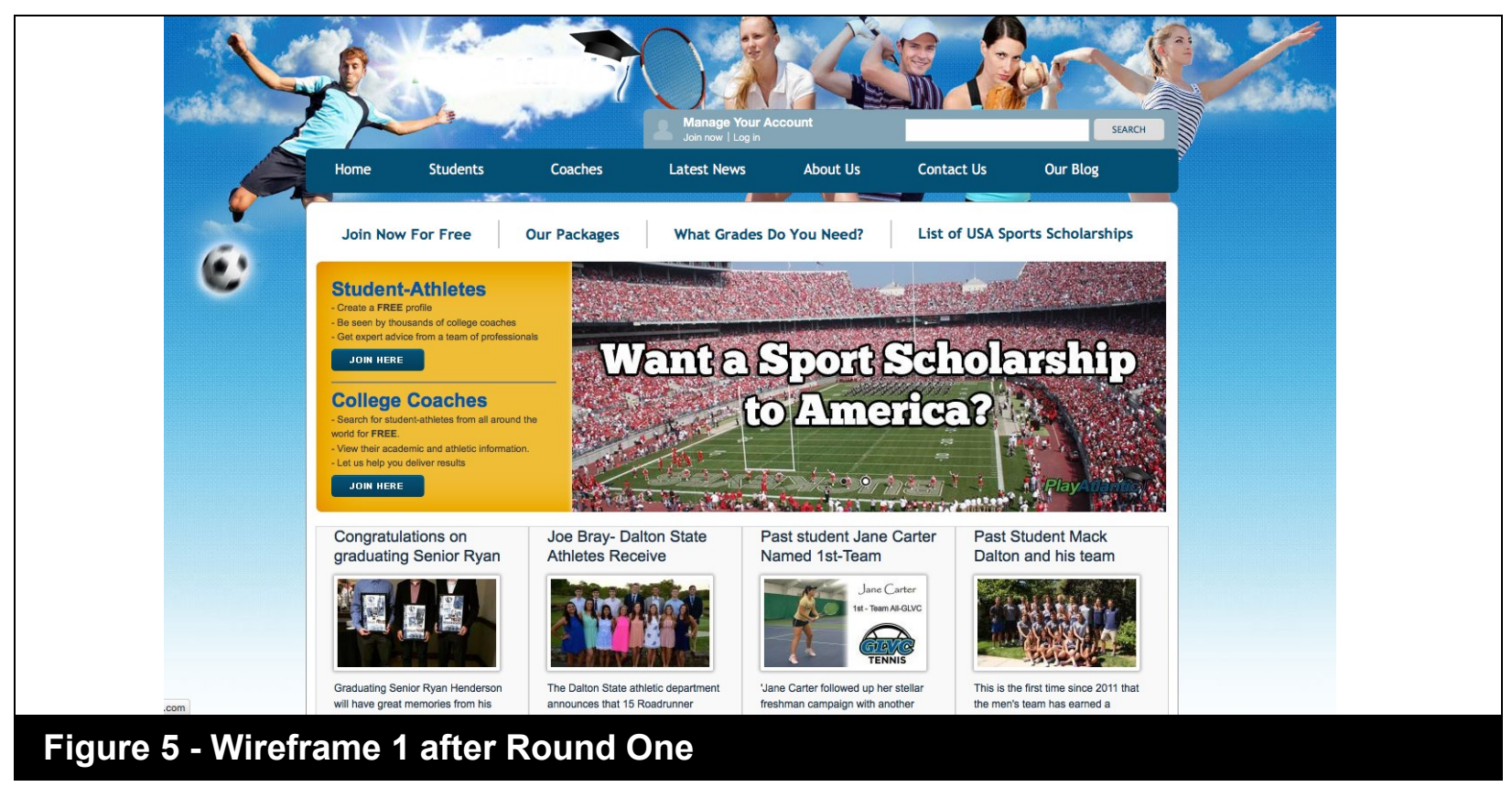

Psychological Values: Users' first impression of the website was that its design reflected a well-organized company. Most of the users felt the layout was compelling and assured. The website provided an impression of the organization as being of a substantial size and professional. The design and content of the website was up to social and sports academy standards. The parents and coaches felt reassured because they could look at the profile of the student athletes, their achievements, progress and testimonials on the website. This provided an insight into the organization's activities.

Emotional Values: Most users were pleased with the robust and detailed way their requests had been integrated. For example, the website had various options for users to interact with the organization, such as having a call-back option and comments in the coaches' section. This led to the users feeling valued, because the designer had recognized and integrated their requests in the design. They appreciated the efforts of the designer in getting to know them before building the website. In addition, the testimonials provided emotional insights that users could refer to and reflect on while making their decisions.

Sociological Values: The designer integrated media channels that were topical and relevant for teenagers, such as Facebook, YouTube, a blog, and Twitter. That way, users who are socially active online could connect with the firm through familiar means, and be part of the firm's community. The respondents commented that they would recommend this website to others interested in sports as a career. The website did not provoke any issues related to social, cultural or family values.

Cognitive Values: The website was very simple and practical to use- with a few clicks, one could access the information needed. The fonts and colors were well-chosen, so that users felt confident and enjoyed the journey. The navigation was user-friendly and finding the information was not stressful. The navigational hierarchy was logical and focused on making a right decision. One of the users felt that it might be a challenge to find important information, such as student packages or FAQ's, as they were located at the bottom panel. The information was there but the respondent felt that users would not look at the bottom of the site to find 
important information. Users experienced some inconsistency in their understanding of section headings, such as "About Us", "Students", "Athletes" and especially "Blog". This indicated that these terms could be challenging for parents who were not frequent computer or Internet users.

From the cognitive aspect, users are familiar with using navigation menus at the top of a webpage, and thus focusing on navigation menus placed at the bottom of the page takes time. This indicates the need for a drop-down menu at the top of the webpage. The additional media elements were too distracting and diverted the focus of users from the main content. From the aspect of personal concerns, the parents preferred to see the information on membership upfront and not be hidden in the sub-sections of the website. They wanted the organization to be clear about its costs so that no hidden tactics would be used while enrolling students. This would increase the credibility of the organization. In terms of the users' psychological and emotional needs, there were some comments from users regarding the affiliation of the organization with American universities. They wanted testimonials from these universities so that they could be confident about the organization. Finally, more information on the organization was provided in the "About Us" section, as the users wanted to know more about the organization so that they would feel assured about its credibility.

\section{Final Design}

After the above feedback, some changes were made to the website. For example, a drop-down menu and a navigation bar at the bottom of the screen were added, so that users had more navigation options. If users were focusing on the top section of the page, they could use the drop-down menu, and if they were focused at the bottom of the page, they could use the bottom navigation. In addition, since some users were unable to concentrate on the information as the animation on the home page was too fast, it was slowed down. The image below (Figure 6 ) reflects the changes that were made after the final round of feedback.

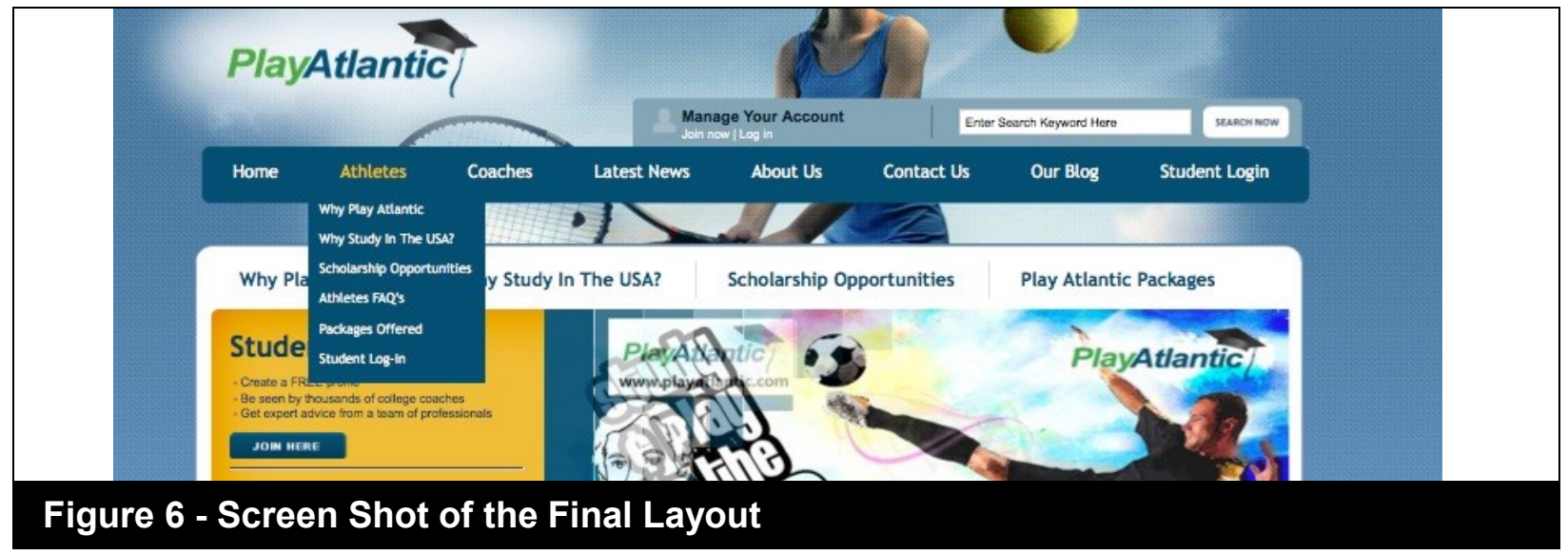

\section{Evaluation of the New Design Process}

This section describes the methods used to evaluate the artefact created during this study. The choice of evaluation methods followed an analysis based on Pries-Heje, Baskerville, \& Venable's (2008) framework for evaluating design science artefacts. It has two dimensions: time of evaluation (exante vs. ex-post) and type of evaluation (naturalistic vs. artificial) (Figure 7). 


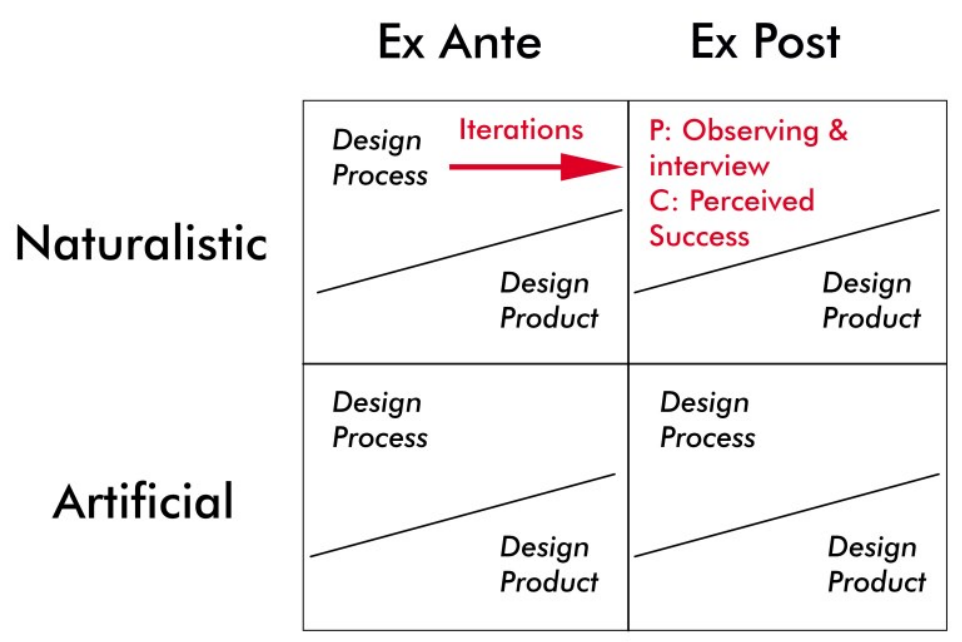

\section{Figure 7 - Design Science Evaluation Framework (Pries-Heje et al., 2008)}

The framework is useful because it recognizes the different perspectives researchers have to consider when deciding how they will evaluate an artefact. Triangulating the results of multiple approaches enhances the reliability of the evaluation process (cf. Isbister et al., 2006). Based on this framework, three evaluation methods were chosen for this artefact: user task analysis, in-depth interviews, and expert review analysis (Table 3 ). The indepth interviews were used to evaluate the product (website) and the process, user task analysis was used to evaluate the product (website), and the expert reviews were used to evaluate the design process. The different evaluation methods fit the framework in the following way:
- What is being evaluated? Both the design process (the Multidisciplinary Design Process) and the final product (the completed website) were evaluated.

- How is it evaluated? The use of interviews to evaluate the process is a naturalistic approach, while expert evaluation and user task analysis are more artificial.

- When is it evaluated? The artefact was evaluated ex post, that is, after it was developed.

- Who is evaluating it? Users and designers evaluated the artefact.

\section{Table 3 - Evaluation Methods Used in this Study}

\begin{tabular}{|c|c|c|}
\hline $\begin{array}{l}\text { EVALUATION } \\
\text { METHOD }\end{array}$ & ARTEFACT & GOAL OF EVALUATION \\
\hline User Task Analysis & \multirow{2}{*}{$\begin{array}{l}\text { Design Product } \\
\text { (Website) }\end{array}$} & To test the usability and functionality of the website. \\
\hline In-Depth Interviews & & $\begin{array}{l}\text { To whether users were satisfied with the integration } \\
\text { of their needs. }\end{array}$ \\
\hline $\begin{array}{l}\text { Expert Review Analysis } \\
\text { 1. Survey } \\
\text { 2. Interview }\end{array}$ & Design Process & $\begin{array}{l}\text { To compare existing design processes with the new } \\
\text { design process over their ability to achieve various } \\
\text { outcomes. }\end{array}$ \\
\hline
\end{tabular}




\section{User Task Analysis}

User task analysis provides a complete description of tasks, sub-tasks, and the methods required to use an interface in order to perform tasks (Wright \& Monk, 1998). Evaluating with users can provide valuable insight into users' interaction which can then be used to improve the overall user experience (Tomeo, 2012). While competing a given set of tasks, users will occasionally be asked questions such as "What will the system do if the image is slow to appear?" or "Why did you click on this button?" When the user asks questions about what to do next, the evaluator asks further questions about the operations available, their interpretation of the screen, and so on. The goal is to analyze how users interact with the interface, so as to assess the efficiency and effectiveness of the website's design. Six participants were randomly selected from a sample of college students and parents for this evaluation phase. They were encouraged to say out loud the information that they were processing while performing the tasks. Prompting and echoing was used to encourage participants to think out loud. The tasks were selected based on the expectations of what the users of this website (athletes, coaches and parents) would accomplish through the site. Each participant was asked to perform five tasks, such as "Find athletes who play tennis", "Find the video of a selected player" and "Find information for parents who wish to enroll their children".

The users took between five and ten seconds to complete all of the tasks. The users' comments were transcribed and coded into themes corresponding to the different disciplines in Brown's (1999) and Shneiderman's (1998) framework (Figure 2).

- Psychological Needs: The findings of this study show how users react and how they are behaving when they seek online information. When users interact with new artefacts, they usually relate what they encounter to what they have seen and assume that their past experiences are the norm for all online information. It is much easier to communicate with users visually. Graphics allow users to compensate for missing cues in text using images, sounds and other interactive elements (Shao, 2009).

- Emotional Needs: Users felt emotionally connected to the website because of the interactive elements, video testimonials and blog posts. Since the content of these sections was created by other users, the respondents empathized with their experiences.

- Cognitive Needs: Cognitive needs include language, memory, perception, learning, and attention. Most users searched for information by scanning the section headings and links to the relevant sections. Only a few users read all of the information on the website. While interactive elements are usually more effective than text for conveying information (Suh, Lim, Kwak, \& Pedersen, 2010), most of the users found the animations distracting because they interfered with their mental processes; this was correlated with the hand movements.

- Social Needs: Users felt safe and secured when they saw videos and blogs from other users. Connecting and communication with other users using chat, email and message boards provided a sense of community and belongingness. Such direct or indirect interaction for individuals is important to fulfil their social interaction needs.

The user task analysis revealed that the website met the users' functionality and usability needs. Users could access the content of the website and navigate easily. Most users were satisfied with the usability criteria such as accessibility, navigation, consistency in design and attractiveness of the website (Nielsen, 1993). The results indicate that the new design process 
effectively meets the usability and functionality requirements of a website.

\section{In-depth Interviews}

The users who participated in round one and two of the design process were interviewed again. Overall, they recognized the improvements in the website from the first round of interviews to the final design of the website. As expected, they rated the website as having a high level of usability. They also felt that their psychological, social, personal and cognitive needs, which had been clarified in Round Two of the design process, had been integrated in the final design of the website. For example, the comprehensive information on the student athletes who had signed up with the firm made it look reputable and established. The increase in the number of navigation options reassured the users that they would not get lost while browsing it. Overall, the website appeared safe and trustworthy, and exuded confidence.

\section{Expert Review}

An expert review was used to compare existing design processes with the new design process developed in this study. The expert review was conducted using two methods: a survey and interviews.

Survey: Since studies have shown that the feedback of experts is useful for evaluating design artefacts, (Cuomo \& Bowen, 2003; Desurvure, Kondziela, \& Atwood, 1992; Doubleday, Ryan, Springett, \& Sutcliffe, 1997; Jeffries, Miller, Wharton, \& Uyeda, 1991; Peng, Ramaiah, \& Foo, 2004), ten expert designers were asked to evaluate the new website design process. They were selected using the snowball method from across different fields of design (Table 4), and were asked to compare existing website design processes with the new design process. They were provided with a short explanation of the design processes and a Likert scale (1-5) was used to assess their level of agreement with the statements in the questionnaire.

\footnotetext{
Table 4 - Summary of Backgrounds of Expert Designers

\begin{tabular}{|c|c|}
\hline CHARACTERISTICS & DESCRIPTION \\
\hline Years of Design Experience & $\begin{array}{l}\text { Eight participants with more than } 10 \text { years of experience in the design } \\
\text { industry, and two with more than four years of experience. }\end{array}$ \\
\hline Professions & $\begin{array}{l}\text { - Senior web designer and university researcher - } 2 \\
\text { The designer had two years of experience in designing interface } \\
\text { and good knowledge of design layout principles. The researcher } \\
\text { was more experienced in conducting academic research on } \\
\text { websites and was from the transdisciplinary area of marketing } \\
\text { communication. } \\
\text { - Senior software designer - } 3 \\
\text { The software designers were experienced in developing user- } \\
\text { based software using the agile and waterfall methodologies. They } \\
\text { have experience of working with large corporations in the financial } \\
\text { and insurance industries. } \\
\text { Senior print designer - } 2 \\
\text { They have worked in the print industry and have deep knowledge } \\
\text { of information design, and in designing layouts and typefaces using } \\
\text { Adobe InDesign and lllustrator. } \\
\text { - Senior system designer from the telecommunication industry - } 1 \\
\text { This designer has worked with a telecommunications firm to design } \\
\text { user experience systems and customer applications. } \\
\text { Freelance web designer - } 2 \\
\text { They have worked as freelancers, designing e-commerce websites } \\
\text { for clients in collaboration with database experts. }\end{array}$ \\
\hline
\end{tabular}
}


The results (Table 5) show that the experts perceived differences in the emphasis placed by the different processes in their integration of users in the design process. The usability (Nielsen, 1993), user-based (Abels et al., 1998) and participatory design processes (Spinuzzi, 2005) involve users in the initial stages to identify their needs, goals and objectives. Most of the expert designers preferred a combination of the user-based design model (Abels et al., 1998) and the participatory design process (Spinuzzi, 2005), which explores the goals and objectives of users, as well as the needs of clients and website developers.
The questions asked during the interview process were based on the based on usability theory (Nielsen, 1993), user-based (Abels et al., 1998) and participatory design processes (Spinuzzi, 2005) and multidisciplinary principles (Brown, 1999). The designers agreed that, while an appreciation of the broader needs of users is important for effective design, not many design processes integrate them well. The designers strongly agreed that the new multidisciplinary design process integrated all the needs of users. They were unsure if the other processes did so as the issue was not clearly specified in their descriptions.

\section{Table 5 - Summary of Expert Designers' Survey Responses}

\begin{tabular}{|c|c|c|c|c|c|}
\hline $\begin{array}{l}\text { EVALUATION CRITERIA: DOES THE } \\
\text { PROCESS... }\end{array}$ & $\begin{array}{l}\text { USABILITY } \\
\text { DESIGN } \\
\text { PROCESS }\end{array}$ & $\begin{array}{l}\text { ITERATIVE } \\
\text { DESIGN } \\
\text { MODEL }\end{array}$ & $\begin{array}{l}\text { USER } \\
\text { BASED } \\
\text { DESIGN } \\
\text { PROCESS }\end{array}$ & $\begin{array}{l}\text { PARTICIPATORY } \\
\text { DESIGN } \\
\text { METHODOLOGY }\end{array}$ & $\begin{array}{l}\text { NEW } \\
\text { DESIGN } \\
\text { PROCESS }\end{array}$ \\
\hline $\begin{array}{l}\text { Involve users from the initial } \\
\text { stage? }\end{array}$ & 4.4 & 2.8 & 4.8 & 4.4 & 4.4 \\
\hline $\begin{array}{l}\text { Collect data on needs \& } \\
\text { expectations of users? }\end{array}$ & 4.0 & 3.2 & 4.6 & 4.6 & 4.8 \\
\hline Use early prototyping? & 4.2 & 3.6 & 4.2 & 4.4 & 5.0 \\
\hline $\begin{array}{lr}\begin{array}{l}\text { Analyze users' } \\
\text { intelligence } \\
\text { requirements)? }\end{array} & \begin{array}{r}\text { language and } \\
\text { (cognitive }\end{array} \\
\end{array}$ & 3.4 & 3.2 & 4.0 & 3.6 & 5.0 \\
\hline $\begin{array}{l}\text { Understand users' feelings, } \\
\text { induce trust, and create a } \\
\text { relationship with the organization } \\
\text { (emotional needs)? }\end{array}$ & 3.2 & 2.8 & 3.6 & 3.8 & 5.0 \\
\hline $\begin{array}{l}\text { Continuously perform iteration of } \\
\text { design solutions? }\end{array}$ & 4.0 & 3.8 & 4.2 & 4.4 & 5.0 \\
\hline $\begin{array}{l}\text { Analyze users' thinking and visual } \\
\text { communication styles (mental } \\
\text { models)? }\end{array}$ & 3.8 & 3.2 & 3.8 & 3.6 & 5.0 \\
\hline $\begin{array}{l}\text { Understand users' social and } \\
\text { cultural values and behaviors } \\
\text { (social needs)? }\end{array}$ & 3.6 & 2.8 & 3.6 & 3.8 & 5.0 \\
\hline $\begin{array}{l}\text { Assess users' short-term memory } \\
\text { and use of devices (physical } \\
\text { limitations)? }\end{array}$ & 3.6 & 3.0 & 3.6 & 3.4 & 4.6 \\
\hline $\begin{array}{l}\text { Pay attention to the } \\
\text { multidisciplinary aspects of design } \\
\text { in the design process? }\end{array}$ & 3.6 & 3.0 & 3.4 & 3.8 & 5.0 \\
\hline $\begin{array}{l}\text { Evaluate the website's usability } \\
\text { using performance tasks? }\end{array}$ & 4.6 & 3.2 & 4.2 & 4.2 & 5.0 \\
\hline
\end{tabular}


Interviews: The designers who participated in the survey were also interviewed to obtain further insight into their views. 20 to 35 minutes long semi-structured interviews were conducted with each expert. They felt that the new design process was resourceintensive, because designs were created over two phases, not in a single round. However, the benefit of that approach was that issues that were not addressed in the first round could be covered in the second round. This was important because it would be difficult for the designer to modify a design after the website has been deployed. The experts thought that the clearly-defined steps of the process would make it easier for designers to communicate their plan to their clients and obtain their approval.

Overall, the results of the different evaluation methods show that the new design process succeeds in achieving its goals: the task analysis revealed that it created a usable website, users agreed that their broader needs were addressed, and design experts praised its completeness and rigor. These results indicate that the new design process is an improvement on existing design processes.

\section{Conclusion}

This study used design science methods to develop a new website design process. The study was motivated by the difference between the emphasis placed on humancentered design in the wider field of design and the focus on usability that pervaded the field of website design. This distinction meant that website design methodologies had not integrated the broader needs of users, such as their cognitive, social and psychological needs, into the design of the websites. Due to the nature of the web application development environment, time schedules for development are relatively short. Therefore, traditional software design methods are less suited for web design (French, 2011, Sajjadi \& Troyer, 2015). While attempts have been made to integrate principles from various disciplines into $\mathrm{HCl}$ and software design methodologies, the processes that have been developed fail to consider the broader aspects of users' needs (Alghamdi, Aldabbas, Alshehri \& Nusir, 2012).

The new design process created here was instantiated by using it to create a new corporate website, and the process and website were then evaluated by users and design experts. The results show that involving users from the initial stage of the design process is important for increasing the effectiveness and acceptance of websites, because their needs are understood and integrated in the site's design. The experience of the instantiation pointed out that the new design process can be feasibly implemented by boutique and freelance designers, who mostly work within time and budget limitations.

\section{Contribution to Research}

The study integrated concepts from the wider field of design with website design to make the latter a much more holistic activity. Gregor \& Jones differentiated between different levels of contributions from design science studies (Gregor \& Jones, 2007; Gregor \& Hevner, 2013), and we discuss how this study provided input at all of these levels.

Level 1: Artefact or situated implementation: The artefact developed in this study is a new website design process. The final artefact extends the focus of existing design processes by integrating the needs of users apart from usability. In addition, the evaluation process used in this study provides an example of assessing artefacts from a broader set of respondents and perspectives. Existing evaluation frameworks focus on usability tests, which prevent designers from obtaining deeper insights into user behavior (Tarasewich, 2003). Combining the evaluation of usability, the incorporation of users' multiple needs, 
and expert opinions leads to a more holistic and rigorous evaluation process.

Level 2: Design principles: The website design process developed here was structured around the principles of multidisciplinary design (Baddeley, 1997; Brown, 1999; Dray \& Seigel, 2007; Egger, 2001; Endsley, Bolte, \& Jones, 2003). These principles are a useful framework for user-centered design and can be applied by designers of other types of interfaces and media in the information systems field.

Level 3: Emergent design theory about embedded phenomena: Design theory in information systems has many different labels, such as the constructive approach (livari et al., 1998), the system development approach (Gregor \& Jones, 2007; Nunamaker et al., 1991) and the design science approach (Hevner et al., 2004; March \& Smith, 1995). The common focus of these design theories has been to explain how an artefact should be built (development process knowledge) and what it should look like when it is built (design principles). This study argues that design in the information systems field should incorporate an awareness and understanding of a broad range of human needs, and move away from the existing emphasis on usability. IS designers can accomplish this by incorporating multidisciplinary design principles into their design processes. The website design theory developed in this study is an example of the types of theories that can be developed by the integration of multidisciplinary principles with existing design methodologies.

\section{Contribution to Practice}

The study has important contributions for both web designers and corporate managers. Many researchers have raised serious concerns about the design and evaluation of websites (Deshpande et al., 2002; Escott, Strooper, King, \& Hayes, 2012; Lille et al., 2009). Normally, website designers do not like to follow any process, as it could constrain their work and take up too much time to apply. The simplicity and clarity of the new process means that website designers can use it to enhance the quality of their output, and ensure that their clients are more satisfied. Managers benefit from an efficient methodology that will help develop more effective and widely-accepted websites. The freelance designers or small design firms that pervade the web design industry are usually unable to dedicate time for research on users and rely on ad hoc design processes. They will be able to use the structured process presented here to enhance the quality of their output. As a result, website failures due to a lack of recognition of users' needs and requirements can be reduced. This will arguably help firms become more successful in e-business.

\section{Limitations}

The factors below may be seen as potentially limiting the study's conclusions and should be considered when evaluating its results. Besides interviews, users' needs could have been assessed through other methods, such as observation, emo cards, focus groups, and cognitive walkthroughs. The selection of method depends on the skills of the designer, the time available, and the resources allocated. These can be incorporated into alternative versions of the methodology and their differential value can be compared. It was a challenge to transform the different types of users' needs into a visual format, because users perceived the meaning of each type of need differently. To some extent, the use of a standard interview protocol may help in this regard.

The challenge with a design science study is that no control group exists against which the results of the new process can be compared. In other words, an equally effective website could be created using another design process. While multiple evaluation methods were used to address this shortcoming, it is challenging to conclusively show that the new process is 
better than existing processes without conducting a very intensive comparison of the outcomes of instantiations of the different design processes in similar firms with similar designers. This could be part of a behavioral science approach to answer the research question. A sample of web design firms could be recruited and the type of process that they use could be manipulated so that the extent and significance of its impact could be assessed.

\section{Future Research}

The study's results provide a firm basis for future research to further improve the quality of the interfaces and other artefacts that we interact with daily. A simple extension would be to instantiate the new process in larger firms and with different types of media (such as e-books, mobile applications, and games) to evaluate its usefulness in a broader context. A sample of firms that are in the process of designing websites could be recruited and the type of process that they used could be manipulated so that the extent and significance of process choice could be assessed. Another approach would be to survey firms about their website design processes, categorize them by the breadth with which they captured users' needs, and then relate these to various aspects of the websites, including usability, sense of community, and firm perception.

The website design theory developed in this study is an example of the type of theory that can be developed by the integration of multidisciplinary principles with existing design methodologies. There is scope for potential theory development by integrating the principles of design science and the design theories such as classical and semiotics design theories. The evaluation framework is also applicable to processes that are not necessarily technology-based. For example, it can be applied to processes where users are vital parts of the artefact, such as business processes, service innovations, and maturity models.

\section{References}

Abels, E. G., White, M. D., \& Hahn, K. (1998). A user-based design process for Web sites. Electronic Networking Applications and Policy, 8, 39-48.

Acharya, R. N., Kagan, A., Lingam, S. R., \& Gray, K. (2008). Impact Of Website Usability On Performance: A Heuristic Evaluation Of Community Bank Homepage Implementation. Journal of Business and Economics Research, 6(6), 139-148.

Albers, M. J., \& Still, B. (2011). Usability of Complex Information Systems: Evaluation of User Interaction. Florida, USA: CRC Press.

Alghamdi, A., Aldabbas, H., Alshehri M \& Nusir, M (2012). Adopting UserCentred Development for Arabic ECommerce Websites.International Journal of Web \& Semantic Technology, 3(2), 1-17.

Al-Qirim, N. A. Y. (2004). Electronic Commerce in Small to Medium Sized Enterprises: Frameworks, Issues and Implications. London: Idea Group Publishing, Hershey, PA.

Axelsson, K., Melin, U., \& Lindgren, I. (2010). Exploring the Importance of Citizen Participation and Involvement in E-government Projects. Transforming Government: People, Process and Policy, 4(4), 299-321.

Baddeley, A. D. (1997). Human Memory. Hove UK: Psychology Press.

Bhan, N. (2012). Why is design important? Retrieved 7th April, 2016, from http://nitibhan.com/2012/09/04/why-isdesign-important/

Black, A. (2007). User-Centered Design. Retrieved 7th April, 2016, Archived at http://webarchive.nationalarchives.gov .uk/20080305120035/http://www.desig ncouncil.org.uk/en/AboutDesign/Design-Techniques/Usercentred-design-I 
Blumler, G. J., \& Katz, E. (1974). The Uses of Mass Communication: Current Perspectives on Gratifications Research. Beverly Hills.

Bostock, M., \& Heer, J. (2009). Protovis: A Graphical Toolkit for Visualization. IEEE Transactions on Visualization and Computer Graphics, 15(6), 11211128.

Boztepe, S. (2007). User Value: Competing Theories and Models. International Journal of Design, 1(2), 55-63.

Brown, M. (1999). Human-Computer Interface Design Guidelines. Great Britain: Intellect Books. School of Art and Design. Exeter.

Brown, T. (2009). Change By Design. New York: Harper Collins.

Bullinger, H.-J., Bauer, W., Wenzel, G., \& Blach, R. (2010). Towards user centred design (UCD) in architecture based on immersive virtual environments. Computer and Information Science, 1-8.

Cagan, J., \& Vogel, C. M. (2002). Creating Breakthrough Products: Innovation From Product Planning To Program Approval. Upper Saddle River, New Jersey: Prentice Hall.

Carroll, J. M. (Ed.). (2003). HCl Models, Theories, And Frameworks: Toward A Multidisciplinary Science. Morgan Kaufmann.

Cho, Y., \& Ha, J. (2011). Users' Attitudes Toward Movie-Related Websites and E-satisfaction. Journal of Business and Economics Research, 2(3), 13-26.

Cuomo, D. L., \& Bowen, C. D. (2003). Understanding Usability Issues Addressed by Three User-system Interface Evaluation Techniques. Interacting with Computers, 6(1), 86108.

Cyr, D. (2008). Modelling Web Site Design Across Cultures: Relationships to Trust, Satisfaction and E-loyalty.
Journal of Management Information Systems, 24(4), 47-72.

Deshpande, Y., Murugesan, S., Ginige, A., Hansen, S., Schwabe, D., Gaedke, M., \& White., B. (2002). Web Engineering. Journal of Web Engineering, 1(1), 317.

Desurvure, H., Kondziela, J., \& Atwood, M. E. (1992). What is Gained and Lost when Using Evaluation Methods other than Empirical Testing. Proceeding of $\mathrm{HCl}$ '92: People and Computers VII, 89-102.

Doubleday, A., Ryan, M., Springett, M., \& Sutcliffe, A. (1997). A Comparison of Usability Techniques for Evaluating Design. Proceedings of the Conference on Designing Interactive Systems: Processes, Practices, Methods, and Techniques, 18-20, 101-110.

Dray, S. M., \& Seigel, D. A. (2007). Understanding Users In Context: An In-Depth Introduction to Fieldwork for User Centered Design. Interact 2007, 712-713.

Dybala, P., Ptaszynski, M., Rzepka, R., \& Araki, K. (2010). Evaluating Subjective Aspects of $\mathrm{HCl}$ on an Example of a Non-Task Oriented Conversational System. International Journal on Artificial Intelligence Tools, 19(6), 819856.

Eco, U. (1979). A Theory of Semiotics. Milan, USA: Indiana University Press.

Egger, F. N. (2001). Affective Design of ECommerce user Interfaces: How to Maximise Perceived Trustworthiness. The International Conference on Affective Human Factors Design, 317324.

Endsley, M. R., Bolte, B., \& Jones. D. G. (2003). Designing for Situation Awareness: An approach to user centered Design. New York: Taylor \& Francis. 
Escott, E., Strooper, P., King, P., \& Hayes, I. J. (2012). Model-Driven Web Form Validation with UML and OCL. In Current Trends in Web Engineering, 223-235: Springer Berlin Heidelberg.

Fei, Y. M., Lin, C. J., \& Chen, J. C. (2007). Verification of a Computer Assisted Creativity Assessment System. In Proceedings of the 37th International Conference on Computers and Industrial Engineering, 512-519.

Fisher, J., Craig, A., \& Bentley, J. (2002). Evaluating Small Business Web Sites - Understanding Users. European Conference on Information Systems, 667-675.

French, A. M. (2011). Web Development Life Cycle: A New Methodology for Developing Web Applications. Journal of Internet Banking and Commerce, 16(2-11).

Garrett, J. J. (2002). The Elements of User Experience: User Centered Design for the Web: New Rides Publishing US.

Green, D. T., \& Pearson, M. J. (2011). Integrating Website Usability with the Electronic Commerce Acceptance Model. Behaviour \& Information Technology, 30(2), 181-199.

Gregor, S., \& Jones, D. (2007). The Anatomy of a Design Theory. Journal of the Association for Information Systems, 8(5), 312-335.

Gregor, S., \& Hevner, A. R. (2013). Positioning and Presenting Design Science Research for Maximum Impact. MIS Quarterly, 37(2), 337-356.

Hevner, A. R., \& Chatterjee, S. (2010). Design Science Research in Information Systems. Integrated Series in Information Systems, 22, 921.

Hevner, A. R., March, S. T., Park, J., \& Ram, S. (2004). Design Science in
Information Systems Research. MIS Quarterly, 28, 75-105.

Hippel, E. V. (1986). Lead Users: A Source of Novel Product Concepts, Management Science, 32(7), 791-805.

Holzinger, A. (2005). Usability Engineering Method for Software Developments. Communication of the ACM, 48(1), 71-75.

Hooper, C. J., \& Dix, A. (2012). Web science and human-computer interaction: when disciplines collide. In Proceedings of the 4th Annual ACM Web Science Conference (pp. 128136).

Humphreys, T., Leung, L., \& Weakley, A. (2008). Embedding Expert Users in the Interaction Design Process: A Case Study. Design Studies, 29(6), 603-622.

Isbister, K., Hook, K., Sharp, M., \& Laaksolathi, J. (2006). The Sensual Evaluation Instrument: Developing an Affective Evaluation Tool. Conference on Human Factors in Computing Systems, 1163-1172.

Issa, T., \& Turk, A. (2012). Applying Usability and $\mathrm{HCl}$ Principles in Developing Marketing Websites. International Journal of Computer Information Systems and Industrial Management Applications, 4, 76-82.

livari, J., Hirschheim, R., \& Klein, H. K. (1998). A Paradigmatic Analysis Contrasting Information Systems Development Approaches and Methodologies. Information Systems Research, 164-193.

Jeffries, R., Miller, J. R., Wharton, C., \& Uyeda, K. M. (1991). User Interface Evaluation in the Real World: A Comparison of Four Techniques. In CHI '91: Proceedings of the Conference on Human Factors in Computing Systems - Reaching through Technology, 119-124. 
Jiang, Z., Chan, J., Tan, B. C., \& Chua, W. S. (2010). Effects of interactivity on website involvement and purchase intention. Journal of the Association for Information Systems, 11(1), 34.

Johnson, J., \& Henderson, A. (2012). Usability of Interactive Systems: It Will Get Worse Before it Gets Better. Journal of Usability Studies, 7(3), 88-93.

Kim, L., Young, A. J., \& Neimeyer, R. A. (2008). Keeping Users at the Center: Developing a Multimedia Interface for Informed Consent. Technical Communication Quarterly, 17(3), 335357.

Kim, W. C., \& Mauborgne, R. (2005). Blue Ocean Strategy: From theory to practice. California Management Review, 47(3), 105-235.

Kjeldskov, J., \& Paay, J. (2012). A Longitudinal Review of Mobile $\mathrm{HCl}$ Research Methods. In Proceedings of the 14th International Conference on Human-Computer Interaction with Mobile Devices and Services (pp. 6978).

Krieger, M. (2008). End User Participation in Design Through Collaborative, Crowdsourced Storyboards. Stanford University $\mathrm{HCl}$ Group 1-2.

Kules, B., \& Shneiderman, B. (2007). Users can Change their Web Search Tactics: Design Guidelines for Categorized Overviews. Information Processing and Management, 44, 463-482.

Kvan, T. (2000). Collaborative Design: What is it? Automation in Construction, 409415.

Lamb, R., \& Kling, R. (2003). Reconceptualizing Users as Social Actors in Information Systems Research. MIS Quarterly, 27(2), 197235.

Lauer, D. A., \& Penthak, S. (1985). Design Basics. New York, NY.
Lee, Y., \& Kozar, K. A. (2006). Investigating the effect of website quality on ebusiness success: An analytic hierarchy process (AHP) approach. Decision Support Systems, 42(3), 1383-1401.

Levy, M., \& Powell, P. (2005). Strategic Intent and E-business in SMEs. Resource and Management Journal, 18(4), 1-20.

Lille, C. D., Stappers, P. J., \& Lugt, R. d. (2009). Searching for User Involvement in SME Design Practice. International Association of Societies of Design Research 2009, 2213-2122.

Lopatovska, I., \& Arapakis, I. (2010). Theories, Methods and Current Research on Emotions in Library and Information Science, Information Retrieval and Human-Computer Interaction. Information Processing and Management, 1-18.

Lowe, D. B., \& Eklund, J. (2002). Client Needs and the Design Process in Web Projects. Journal of Web Engineering, 1(1), 23-36.

Luo, X. (2002). Uses and Gratifications Theory and E-Consumer Behaviors: A Structural Equation Modeling Study. Journal of Interactive Advertising, 2(2), 34-41.

Mao, J.-Y., Vredenburg, K., Smith, P. W., \& Carey, T. (2005). The State of User Centered Design Practice. Communications of the ACM, 48(3), 105-110.

March, S. T., \& Smith, G. F. (1995). Design and Natural Science Research on Information Technology. Decision Support Systems, 15, 251-266.

McGuire, W. J. (1974). Psychological Motives and Communication Gratification: The Uses of Mass Communications. Beverley Hills Saga Publications. 
Mclntyre-Mills, J. (2009). Participatory Design for Democracy and Wellbeing: Narrowing the Gap Between Service Outcomes and Perceived Needs. Science and Business, 21-45.

McLeod, L., MacDonell, S., \& Doolin, B. (2007). User Participation in Contemporary IS Development: An IS Management Perspective. Australasian Journal of Information Systems, 15(1), 113-136.

Moore, P., \& Fitz, C. (1993). Gestalt Theory and Instructional Design. Journal of Technical Writing and Communication, 23, 137-157.

Morrison, P. D., Roberts, J. H., \& Hippel, E. V. (2000). Determinants of User Innovation and Innovation Sharing in a Local market. Management Science, 46, 1513-1527.

Nielsen, J. (1993). Usability Engineering. California: Academic Press.

Norman, D. (2002). The Design of Everyday Things. New York: Basic Books.

Norman, D. A. (1982). Steps Toward a Cognitive Engineering: Design Rules Based on Analyses of Human Error. In J. A. Nichols \& M. L. Schneider (Eds.), Proceedings of the 1982 Conference on Human Factors in Computing Systems (pp. 378 - 382). New York, NY, USA: Association for Computing Machinery.

Nunamaker, J. F., Chen, M., \& Purdin. (1991). T.D.M. Systems Development in Information Systems Research. Journal of Management Information Systems, 7(3), 89-106.

Paas, F., Renkl, A., \& Sweller, J. (2003). Cognitive Load Theory and Instructional Design: Recent Developments. Educational Psychologist, 38(1), 1-4.

Peng, L. K., Ramaiah, C. K., \& Foo, S. (2004). Heuristic based User Interface Evaluation at Nanyang Technological
University in Singapore. Electronic Library and Information Systems, 38, 42-59.

Pries-Heje, J., Baskerville, R., \& Venable, J. (2008). Strategies For Design Science Research Evaluation. European Conference on Information Systems, 87, 255-266.

Qutaishat, F. T. (2013). Users' perceptions towards website quality and its effect on intention to use e-government services in Jordan. International Business Research, 6(1), 97.

Roy, M. C., Dewit, O., \& Aubert, B. A. (2001). The Impact of Interface Usability on Trust in Web Retailers. Electronic Networking Applications and Policy, 11(5), 388-398.

Saariluoma, P., Parkkola, H., Honkatanta, A., Leppanen, M., \& Lamminen, J. (2009). User Psychology in Interaction Design: The Role of Design Ontology: Springer London.

Sajjadi, P., \& Troyer, O. (2015). Revising Web Design to Deal with Current Development Practices. Asia Pacific Conference on Conceptual Modelling, 103-108.

Schubert, P., \& Dettling, W. (2001). Web Site Evaluation: Do Web Applications Meet User Expectations? Music, Consumer Goods and e-Banking on the Test Bed. Bled Conference on Electronic Commerce, 383-403.

Shao, G. (2009). Understanding the Appeal of User-Generated Media: a Uses and Gratification Perspective. Internet Research, 19(1), 7-25.

Shedroff, N. (1999). Information Interaction Design : A United Field Theory. Cambridge: MIT Press.

Shneiderman, B. (1998). Designing the User Interface: Strategies for Effective Human Computer Interaction (Vol. 85). Boston: Addison Wesley. 
Shneiderman, B. (2007). Creativity Support Tools; Accelerating Discovery and Innovation. Communications of the ACM, 50(12), 20-32.

Spinuzzi, C. (2005). The Methodology of Participatory Design. Technical Communication, 52(2), 162-174.

Spivey, M. J. (2007). Redesigning Our Theories Of Human Information Processing. Information Design Journal, 15(3), 261-265.

Stasko, J., Görg, C., \& Liu, Z. (2008). Jigsaw: Supporting Investigative Analysis Through Interactive Visualization. Information Visualization, 7, 118-132.

Suh, Y. I., Lim, C., Kwak, D. H., \& Pedersen, P. M. (2010). Examining the Psychological Factors Associated with Involvement in Fantasy Sports: An Analysis of Participants' Motivations and Constraints. International Journal of Sport Management, Recreation \& Tourism, 5, 1-28.

Tan, F., Tung, L. L., \& Xu, Y. (2009). A Study of Web-designers' Criteria for B2C Website Evaluation using the Repertory Grid Technique. Journal of Electronic Commerce Research, 10(3), 155-177.

Tarasewich, P. (2003). Wireless devices for mobile commerce: user interface design and usability. In B.E. Mennecke \& T.J. Strader (Eds.) Mobile commerce: technology, theory, and applications, Idea Group Publishing, Hershey, PA, pg. 26-50.

Terry, J., \& Standing, C. (2004). The Value of User Participation in E-Commerce Systems Development. Informing Science Journal, 7, 32-45.

Tomayess, I., \& Pedro, I. (2014). Human Computer Interaction and Usability in the New Participative Methodology for Marketing Websites. Pacific Asia Journal of the Association for Information Systems, 6(3).
Tomeo, L Megan. (2012). Adding Users to the Website Design Process. Public Services Quarterly, 8(4), 350-358

Troyer, D., \& C.J.Leune. (1998). WSDM: A User Centered Design Method for Websites. Computer Network and ISDN System, 1-10.

Tung, L.L., Xu, Y. and Tan, F.B. (2009). Attributes of Website Usability: A Study of Web Users with the Repertory Grid Technique. International Journal of Electronic Commerce, 13(4), 99-128.

Vandermerwe, S. (2000). How Increasing Value to Customers Improves Business Results. Sloan Management Review, 42(1), 27-37.

Venable, J. (2006). A Framework For Design Science Research Activities. In Proceedings of the 2006 Information Resource Management Association Conference (pp. 21-24). Washington, DC.

Virzi, R. A. (1996). Usability Problem Identification Using Both Low and High Fidelity Prototypes. SIGCHI Conference on Human Factors in Computing Systems, 236-243.

Walls, J. G., Widmeyer, G. R., \& Sawy, El Sawy O. A. (1992). Building an Information System Design Theory for Vigilant EIS. Information Systems Research, 3(1), 36-59.

Wang, Y. D. (2005). Trust in E-Commerce: Consideration of Interface Design Factors. Journal of Electronic Commerce in Organizations, 3(4), 4260.

Warren, P., Boldyreff, C., \& Munro, M. (1999). The Evolution of Websites. IEEE Computer Society, 178-191.

Wright, P. C., \& Monk, A. F. (1998). The Use of Think Aloud Evaluation Methods in Design. SIGCHI Conference on Human Factors in Computing Systems, 55-57. 
Zhao, H., Plaisant, C., Shneiderman, B., \& Lazar, J. (2008). Data Sonification for Users with Visual Impairment: A Case Study with Georeferenced Data. ACM Transactions on Computer-Human Interaction, 15(1), 1-28.

Zhang, P., \& Von Dran, G. M. (2000). Satisfiers and dissatisfiers: A two factor model for website design and evaluation. Journal of the American society for information science, 51(14), 1253-1268.

Zimmerman, J., \& Forlizzi, J. (2008). The Role of Design Artifacts in Design Theory Construction. HumanComputer Interaction Institute, 1-12.

\section{About the Authors}

Dr. Sangeeta Karmokar is a Senior Lecturer in the Faculty of Creative Technologies, at the Auckland University of Technology. She is interested in fostering creative and critical thinking and providing design-thinking opportunities in building innovative and digital business models. Wanting to expand into the research side of academic life, she completed a $\mathrm{PhD}$ in $\mathrm{E}$ business design for SME. Her practicebased research interest lies at the intersection of the entrepreneurship and design discipline with a special interest in social and women entrepreneurship. The cross-disciplinary teaching and research provided an opportunity and rich experience to work in broader trans-disciplinary environment. Sangeeta has regularly contributed to her local community various activities and working on community based projects.

Dr. Harminder Singh is a Senior Lecturer in the Faculty of Business, Economics \& Law at the Auckland University of Technology, where he teaches courses in information systems strategy, IS governance and business analytics. He received his Ph.D. in 2010 from Michigan State University, where he studied the drift of IS portfolios. His research interests are in the tension between change and control in IT-enabled work environments, and how this is governed. He is also interested in multilevel analysis.

Dr. Felix Tan is Professor and Head of Business at Excelsia College in Sydney, Australia. He was the Editor-in-Chief of the Journal of Global Information Management from 1998 to 2012; and was on the Council of the Association for Information Systems from 2003 to 2005. Prior to joining Excelsia College, Dr Tan was at Auckland University of Technology where he was recipient of the School of Business 2012 Award for Excellence in Postgraduate Supervision and the 2013 Award for Research Excellence. Dr Tan is internationally known for his work in the global IT field. His other research interests include IT user behaviour and the management of IT. Dr Tan has published in MIS Quarterly, Information \& Management, Information Systems Journal, Journal of Information Technology, European Journal of Information Systems as well as other journals and refereed conference proceedings. 